\title{
Performance of Hybrid Fodder Sorghum (Sugargraze)
}

\author{
Harphool Meena ${ }^{*}$,Pratap Singh, S. N. Meena, D. L. Yadav and N. L. Meena \\ Agricultural Research Station, Ummedganj Farm, Agriculture University, \\ Kota-324001 (Rajasthan), India \\ *Corresponding author
}

\section{Keywords}

Sugargraze, seed rate, fodder yield, quality

Article Info

Accepted:

15 April 2020

Available Online:

10 May 2020

\section{A B S T R A C T}

A field experiment was conducted during two consecutive years from 2017 and 2018at Agricultural Research Station Ummedganj, Kota (Rajasthan), sowing of hybrid fodder sorghum (sugargraze) by different seed rates viz. $3.5,5.5,7.5,9.5,11.5 \mathrm{~kg} / \mathrm{ha}$ and local chari $10.0 \mathrm{~kg} / \mathrm{ha}$. The fodder yield of sugargraze was significantly influenced by sowing of different seed rate. Pooled data of two years gave significantly higher green fodder yield( 898 $\mathrm{q} / \mathrm{ha})$ and dry fodder yield (241 q/ha) were observed by sowing of sugargraze $9.5 \mathrm{~kg}$ seed/ha over local chari sowing by $10.0 \mathrm{~kg}$ seed/ha green fodder yield (659 q/ha) and dry fodder yield (166 q/ha). However, it was found at par with sowing of sugargraze by $7.5 \mathrm{~kg}$ seed/ha green fodder yield (887 q/ha) and dry fodder yield (238 q/ha).

\section{Introduction}

Sorghum [Sorghum bicolor (Linn.) Moench] is an important crop in the world, used for food (as grain or sorghum molasses), fodder, the production of alcoholic beverages and biofuels. Most varieties are drought and heat tolerant, and are especially important in arid regions, where the grain is one of the staple food for poor and rural people. It is an important food and fodder crop grown in India, and among cereals, it is the fourth most important crop after rice, wheat and maize (Dehinwal et al., 2016). Sorghum grain is used as staple food by millions of people and is grown for grain in southern and central states of India, whereas in northern states of the country (Punjab, Haryana, Uttar Pradesh, Rajasthan, etc.) it is mainly grown as fodder during summer and kharif seasons as a single as well as multicut crop. Among forage crops, forage sorghum could be a strategic option because of the crop's xerophytic characteristics, adaptation potential, quick 
growing habit, good ratoon ability, palatability, digestibility and wide range of potential uses as green fodder, dry roughage, hay and silage (Kumar and Chaplot, 2015).

Among crop management practices seeding densities or plant population greatly affect crop growth and then finally grain yield. Therefore seeding density is a key factor in assessing the flexibility and yielding ability of cultivars. Both over and substandard plant population is the major cause of low yield (Jan et al., 2000).

Optimum seed rate plays an important role in contributing to the high yield because in case of thick plant population, most plants remain sterile, easily attacked by diseases as compared to normal population(Robert and Singh, 1981).To obtain high quality preserved forage (silage or hay), harvest sugargraze at knee height stage. For silage, let plants wilt prior to ensiling and lower moisture content will reduce effluent losses from silage. In the India, two to three subsequent harvests are possible. To stimulate recovery growth, fertilize with nitrogen immediately following the initial harvest (Smith et al., 2005).

\section{Materials and Methods}

Field experiment was conducted during two consecutive years from 2017 and 2018 at Agricultural Research Station Ummedganj, Kota. The research station is situated in AgroClimatic Zone V (Humid South-Eastern Plain) of Rajasthan.

It is located between $25^{\circ} 13^{\prime} \mathrm{N}$ latitude and $75^{\circ} 25^{\prime}$ E longitudes at an altitude of $258 \mathrm{~m}$ above MSL. The average rainfall of both the years during crop growing season were 496.1 and $545 \mathrm{~mm}$ and means maximum and minimum temperatures $34.6 \& 37.1{ }^{0} \mathrm{C}$ and $16.9 \& 20.6^{0} \mathrm{C}$, respectively. Experimental field was well prepared by two ploughing followed by harrowing \& cultivator and one planking for uniform leveling, etc. were performed for sowing of sugargraze crop. Experiment was laid-out in Randomized Block Design with four replications and six treatments viz. $\mathrm{T}_{1}$ : Sugargraze (seed rate 3.5 $\mathrm{kg} / \mathrm{ha}$ ), $\mathrm{T}_{2}$ : Sugargraze (seed rate $5.5 \mathrm{~kg} / \mathrm{ha}$ ), $\mathrm{T}_{3}$ : Sugargraze (seed rate $7.5 \mathrm{~kg} / \mathrm{ha}$ ), $\mathrm{T}_{4}$ : Sugargraze (seed rate $9.5 \mathrm{~kg} / \mathrm{ha}$ ), $\mathrm{T}_{5}$ : Sugargraze (seed rate11.5 kg/ha) and $\mathrm{T}_{6}$ : Local chari (seed rate $10.0 \mathrm{~kg} / \mathrm{ha}$ ).

The bulk density, $\mathrm{pH}$ and cation exchange capacity of these soils varies between 1.30$1.60 \mathrm{Mg} / \mathrm{m}^{3}, 7.75-8.50$ and $30-40 \mathrm{Cmol} / \mathrm{kg}$, respectively. The soils of the region are poor in organic carbon $(0.50 \pm 0.08)$ and available nitrogen $(275 \pm 5 \mathrm{~kg} / \mathrm{ha})$ but are low to medium in available $\mathrm{P}_{2} \mathrm{O}_{5}(24.2 \pm 1.0 \mathrm{~kg} / \mathrm{ha})$ and medium to high in available $\mathrm{K}_{2} \mathrm{O}(290 \pm 8$ $\mathrm{kg} / \mathrm{ha}$ ). The recommended dose of nitrogen, phosphorus \& potash i.e. $125 \mathrm{~kg}$ N/ha, $60 \mathrm{~kg}$ $\mathrm{P}_{2} \mathrm{O}_{5} /$ ha and $60 \mathrm{~kg} \mathrm{~K} 2 \mathrm{O} /$ ha were given in the form of urea, di-ammonium phosphate (DAP) and muriate of potash (MOP). Full dose of DAP and MOP and half $\mathrm{N}$ were drilled just before sowing and remaining half- $\mathrm{N}$ was applied in two split doses as per recommendation.

\section{Results and Discussion}

\section{First cutting}

The plant population and growth parameters of sugargraze were significantly influenced by sowing of different seed rate (Table 1). Pooled data of two years showed that the significantly higher plant population (491765/ha) of sugargraze was recorded by sowing of $11.5 \mathrm{~kg}$ seed/ha which was significantly superior over rest of the treatments. The maximum plant height $(153.51 \mathrm{~cm})$ was recorded in the first cutting by sowing of sugargraze by $3.5 \mathrm{~kg}$ seed/ha over local chari plant height $(131.98 \mathrm{~cm})$. 
However, it was found at par with sowing of sugargraze by 5.5 and $7.5 \mathrm{~kg}$ seed/ha. These results are in close proximity with those of Dehinwal et al., 2016, Smith et al., 2005 and Jan et al., 2000. Two years data indicated that the maximum leaf weight/plant (93.65 g) and stem weight/plant (280.10 g) were recorded in the first cutting of sugargraze by sowing 3.5 $\mathrm{kg} \mathrm{seed/ha} \mathrm{but} \mathrm{it} \mathrm{was} \mathrm{found} \mathrm{at} \mathrm{par} \mathrm{with}$ sowing of sugargraze by 5.5 and $7.5 \mathrm{~kg}$ seed/ha over local chari leaf weight/plant $(70.5 \mathrm{~g})$ and stem weight/plant $(214.05 \mathrm{~g})$ by sowing of $10 \mathrm{~kg}$ seed/ha in the pooled analysis.

The higher leaf: stem ratio (0.37) was observed in the pooled data of sugargraze by sowing of $3.5 \mathrm{~kg}$ seed/ha over rest of the treatments. These results are in close proximity with those of Satpal et al., 2016, Kumar and Chaplot (2015).

Pooled data of dry matter content was significantly influenced by sowing of different seed rate of sugargraze (Table 2). Sowing of sugargraze by $9.5 \mathrm{~kg}$ seed/ha was recorded maximum dry matter $(26.70 \%)$ but it was found at par with the sowing of sugargraze by $7.5 \mathrm{~kg}$ seed/ha over local chari sowing by $10.0 \mathrm{~kg}$ seed/ha dry matter $(26.53$ $\%)$. Significantly influenced quality parameters of sugargraze by sowing of $9.5 \mathrm{~kg}$ seed/ha, cruid protein (7.14) and cruid fibre (24.90) per cent over local chari sowing by $10.0 \mathrm{~kg} \mathrm{seed} / \mathrm{ha}$. However, it was found at par with the sowing of different seed rate of sugargraze $3.5,5.5,7.5$ and $11.5 \mathrm{~kg}$ seed/ha, respectively.

Two years pooled data indicated that significantly influenced ash content (15.01) per cent in sugargraze by sowing of $9.5 \mathrm{~kg}$ seed/haover local chari (13.99) per cent sowing by $10.0 \mathrm{~kg}$ seed/ha. These results are in close proximity with those of Satpal et al., 2016, Kumar and Chaplot (2015).

\section{Second cutting}

During second cutting plant growth was significantly influenced (Table 3) by sowing of different seed rate of sugargraze. The maximum plant height $(133 \mathrm{~cm})$ of sugargraze was recorded by sowing of $3.5 \mathrm{~kg}$ seed/ha over local chari plant height $(117 \mathrm{~cm})$ sowing by $10 \mathrm{~kg}$ seed/ha. However, it was found at par with sowing of sugargraze by 5.5 and $7.5 \mathrm{~kg} \mathrm{seed} / \mathrm{ha}$, respectively in the pooled analysis.

The maximum leaf weight/ plant (66.17 g) and stem weight/ plant (160.25 g) of sugargraze were recorded by sowing of $3.5 \mathrm{~kg}$ seed/ha over local chari leaf weight/ plant $(51.85 \mathrm{~g})$ and stem weight/ plant (119.05 g) by sowing of $10 \mathrm{~kg}$ seed/ha. However, it was found at par with sowing of sugargraze by 5.5 and $7.5 \mathrm{~kg}$ seed/ha, respectively. Pooled data of two years shows that the significantly higher leaf: stem ratio (0.35) was observed by sowing of sugargraze $3.5 \mathrm{~kg}$ seed/ha over rest of the treatments. These results are in close proximity with those of Dehinwal et al., 2016, Smith et al., 2005 and Jan et al., 2000.

Significantly influenced dry matter (26.94) per cent under sowing of sugargraze by $9.5 \mathrm{~kg}$ seed/ha but it was found at par with the sowing of sugargraze by $7.5 \mathrm{~kg}$ seed/hadry matter (26.73) per cent over rest of treatments (Table 4). Pooled data indicated that the quality parameters of sugargraze cruid protein (6.96) and cruid fibre (24.44) per cent were significantly influenced by sowing of $9.5 \mathrm{~kg}$ seed/ha over local chari sowing by $10.0 \mathrm{~kg}$ seed/ha.

However, it was found at par with the sowing of different seed rate of sugargraze 3.5,5.5,7.5 and $11.5 \mathrm{~kg}$ seed/ha, respectively. The maximum ash content (14.94) per cent was observed in sugargraze by sowing of $9.5 \mathrm{~kg}$ seed/ha over local chari sowing by $10.0 \mathrm{~kg}$ 
seed/ha. However, it was found at par with the sowing of different seed rate of sugargraze $3.5,5.5,7.5$ and $11.5 \mathrm{~kg}$ seed/ha, respectively in the pooled analysis. These results are in close proximity with those of Satpal et al., 2016, Kumar and Chaplot (2015). Significantly higher green fodder yield (898 q/ha) and dry fodder yield (241 $\mathrm{q} / \mathrm{ha}$ ) were observed with sowing of sugargraze by $9.5 \mathrm{~kg}$ seed/ha over local chari sowing by $10.0 \mathrm{~kg}$ seed/ha green fodder yield (659 q/ha) and dry fodder yield (166 q/ha). However, it was found at par with sowing of sugargraze by $7.5 \mathrm{~kg}$ seed/ha green fodder yield (887 q/ha) and dry fodder yield (238 $\mathrm{q} / \mathrm{ha}$ ). These results are in close proximity with those of Satpal et al., 2016, Kumar and Chaplot (2015).

Table.1 Pooled data of plant population, growth parameters, fodder yield and quality of sugargraze during first cutting (2017 and 2018)

\begin{tabular}{|c|c|c|c|c|c|}
\hline Treatments & $\begin{array}{c}\text { Plant } \\
\text { population } \\
(000 / h a)\end{array}$ & $\begin{array}{c}\text { Plant } \\
\text { height } \\
(\mathbf{c m})\end{array}$ & $\begin{array}{c}\text { Weight } \\
\text { of leaves/ } \\
\text { plant (g) }\end{array}$ & $\begin{array}{l}\text { Weight } \\
\text { of stem/ } \\
\text { plant (g) }\end{array}$ & $\begin{array}{l}\text { Leaf : Stem } \\
\quad \text { ratio }\end{array}$ \\
\hline $\begin{array}{l}T_{1}: \text { Sugargraze (seed rate } 3.5 \\
\text { kg/ha) }\end{array}$ & 157440 & 153.51 & 93.65 & 280.10 & 0.37 \\
\hline $\begin{array}{l}\mathrm{T}_{2}: \text { Sugargraze (seed rate } 5.5 \\
\mathrm{~kg} / \mathrm{ha} \text { ) }\end{array}$ & 246240 & 152.39 & 92.65 & 279.45 & 0.36 \\
\hline $\begin{array}{l}T_{3}: \text { Sugargraze (seed rate } 7.5 \\
\mathrm{~kg} / \mathrm{ha} \text { ) }\end{array}$ & 329643 & 150.97 & 92.35 & 278.40 & 0.34 \\
\hline $\begin{array}{l}T_{4}: \text { Sugargraze (seed rate } 9.5 \\
\text { kg/ha) }\end{array}$ & 409765 & 142.23 & 91.25 & 275.55 & 0.33 \\
\hline $\begin{array}{l}\mathrm{T}_{5}: \text { Sugargraze (seed rate } 11.5 \\
\mathrm{~kg} / \mathrm{ha} \text { ) }\end{array}$ & 491765 & 136.01 & 73.5 & 253.05 & 0.31 \\
\hline $\begin{array}{l}T_{6}: \text { Local chari (seed rate } 10.0 \\
\mathrm{~kg} / \mathrm{ha} \text { ) }\end{array}$ & 418000 & 131.98 & 70.5 & 214.05 & 0.26 \\
\hline SEm \pm & 1003 & 1.10 & 0.67 & 1.15 & 0.002 \\
\hline CD at $5 \%$ & 2906 & 2.80 & 1.92 & 3.34 & 0.008 \\
\hline
\end{tabular}

Table.2 Pooled data of dry matter content and quality of sugargraze during first cutting (2017 and 2019)

\begin{tabular}{|c|c|c|c|c|}
\hline Treatments & $\begin{array}{l}\text { Dry matter } \\
(\%)\end{array}$ & $\begin{array}{c}\text { Crude protein } \\
(\%)\end{array}$ & $\begin{array}{l}\text { Crude fibre } \\
\quad(\%)\end{array}$ & $\begin{array}{l}\text { Ash content } \\
\quad(\%)\end{array}$ \\
\hline $\begin{array}{l}T_{1}: \text { Sugargraze (seed rate } 3.5 \\
\mathrm{~kg} / \mathrm{ha} \text { ) }\end{array}$ & 27.62 & 7.15 & 24.88 & 15.05 \\
\hline $\begin{array}{l}\mathrm{T}_{2}: \text { Sugargraze (seed rate } 5.5 \\
\mathrm{~kg} / \mathrm{ha} \text { ) }\end{array}$ & 26.72 & 7.16 & 24.85 & 15.03 \\
\hline $\begin{array}{l}T_{3}: \text { Sugargraze (seed rate } 7.5 \\
\mathrm{~kg} / \mathrm{ha} \text { ) }\end{array}$ & 26.71 & 7.17 & 24.89 & 15.03 \\
\hline $\begin{array}{l}\mathrm{T}_{4} \text { : Sugargraze (seed rate } 9.5 \\
\mathrm{~kg} / \mathrm{ha} \text { ) }\end{array}$ & 26.70 & 7.14 & 24.90 & 15.01 \\
\hline $\begin{array}{l}T_{5}: \text { Sugargraze (seed rate } 11.5 \\
\text { kg/ha) }\end{array}$ & 25.99 & 7.11 & 24.86 & 14.95 \\
\hline $\begin{array}{l}T_{6}: \text { Local chari (seed rate } 10.0 \\
\text { kg/ha) }\end{array}$ & 26.53 & 6.37 & 23.36 & 13.97 \\
\hline SEm \pm & 0.11 & 0.037 & 0.15 & 0.03 \\
\hline CD at $5 \%$ & 0.36 & 0.105 & 0.45 & 0.09 \\
\hline
\end{tabular}


Table.3 Pooled data of plant growth parameters of sugargraze during second cutting

\begin{tabular}{|c|c|c|c|c|}
\hline Treatments & $\begin{array}{c}\text { Plant } \\
\text { height }(\mathbf{c m})\end{array}$ & $\begin{array}{c}\text { Weight of } \\
\text { leaves/plant (g) }\end{array}$ & $\begin{array}{l}\text { Weight of stem/ } \\
\text { plant (g) }\end{array}$ & $\begin{array}{l}\text { Leaf : Stem } \\
\text { ratio }\end{array}$ \\
\hline$T_{1}:$ Sugargraze (seed rate $3.5 \mathrm{~kg} / \mathrm{ha}$ ) & 133 & 66.17 & Pooled & 0.35 \\
\hline $\mathrm{T}_{2}$ : Sugargraze (seed rate $5.5 \mathrm{~kg} / \mathrm{ha}$ ) & 132 & 65.89 & 160.25 & 0.33 \\
\hline$T_{3}:$ Sugargraze (seed rate $7.5 \mathrm{~kg} / \mathrm{ha}$ ) & 131 & 64.88 & 157.60 & 0.32 \\
\hline$T_{4}$ : Sugargraze (seed rate $9.5 \mathrm{~kg} / \mathrm{ha}$ ) & 126 & 62.08 & 156.50 & 0.30 \\
\hline $\mathrm{T}_{5}:$ Sugargraze (seed rate $11.5 \mathrm{~kg} / \mathrm{ha}$ ) & 120 & 55.53 & 156.10 & 0.29 \\
\hline$T_{6}:$ Local chari (seed rate $10.0 \mathrm{~kg} / \mathrm{ha}$ ) & 117 & 51.85 & 135.80 & 0.25 \\
\hline SEm \pm & 0.67 & 0.90 & 119.05 & 0.003 \\
\hline CD at $5 \%$ & 2.01 & 2.69 & 1.33 & 0.010 \\
\hline
\end{tabular}

Table.4 Pooled data of fodder dry matter content and quality of sugargraze during second cutting

\begin{tabular}{|c|c|c|c|c|}
\hline Treatments & $\begin{array}{c}\text { Dry matter } \\
(\%)\end{array}$ & $\begin{array}{c}\text { Crude protein } \\
(\%)\end{array}$ & $\begin{array}{c}\text { Crude fibre } \\
(\%)\end{array}$ & $\begin{array}{c}\text { Ash content } \\
(\%)\end{array}$ \\
\hline$T_{1}:$ Sugargraze (seed rate $3.5 \mathrm{~kg} / \mathrm{ha}$ ) & 25.14 & 6.97 & 24.44 & 14.98 \\
\hline $\mathrm{T}_{2}:$ Sugargraze (seed rate $5.5 \mathrm{~kg} / \mathrm{ha}$ ) & 25.63 & 6.99 & 24.44 & 14.97 \\
\hline$T_{3}:$ Sugargraze (seed rate $7.5 \mathrm{~kg} / \mathrm{ha}$ ) & 26.73 & 6.99 & 24.46 & 14.96 \\
\hline $\mathrm{T}_{4}$ : Sugargraze (seed rate $9.5 \mathrm{~kg} / \mathrm{ha}$ ) & 26.94 & 6.96 & 24.44 & 14.94 \\
\hline$T_{5}:$ Sugargraze (seed rate $\left.11.5 \mathrm{~kg} / \mathrm{ha}\right)$ & 25.05 & 6.80 & 24.46 & 14.91 \\
\hline$T_{6}:$ Local chari (seed rate $10.0 \mathrm{~kg} / \mathrm{ha}$ ) & 22.64 & 5.97 & 23.00 & 13.95 \\
\hline SEm \pm & 0.18 & 0.024 & 0.077 & 0.063 \\
\hline CD at $5 \%$ & 0.52 & 0.067 & 0.23 & 0.18 \\
\hline
\end{tabular}

Table.5 Pooled data of green fodder and dry fodder yield of sugargraze during first and second cutting

\begin{tabular}{|c|c|c|c|c|c|c|}
\hline \multirow[t]{2}{*}{ Treatments } & \multicolumn{2}{|c|}{$\begin{array}{l}\text { Green fodder yield } \\
\text { (q/ha) }\end{array}$} & \multirow{2}{*}{$\begin{array}{l}\text { Total } \\
\text { yield } \\
\text { (q/ha) }\end{array}$} & \multicolumn{2}{|c|}{$\begin{array}{l}\text { Dry fodder yield } \\
(\mathrm{q} / \mathrm{ha})\end{array}$} & \multirow{2}{*}{$\begin{array}{c}\text { Total } \\
\text { yield } \\
\text { (q/ha) }\end{array}$} \\
\hline & $\begin{array}{c}I^{\text {st }} \\
\text { Cutting }\end{array}$ & $\begin{array}{c}\text { II }^{\text {nd }} \\
\text { Cutting }\end{array}$ & & $\begin{array}{l}I^{\text {st }} \\
\text { Cutting }\end{array}$ & $\begin{array}{c}\text { II }^{\text {nd }} \\
\text { Cutting }\end{array}$ & \\
\hline T1: Sugargraze (seed rate $3.5 \mathrm{~kg} / \mathrm{ha}$ ) & 382 & 244 & 626 & 106 & 61 & 167 \\
\hline T2: Sugargraze (seed rate $5.5 \mathrm{~kg} / \mathrm{ha}$ ) & 421 & 260 & 681 & 113 & 67 & 180 \\
\hline T3: Sugargraze (seed rate $7.5 \mathrm{~kg} / \mathrm{ha}$ ) & 556 & 331 & 887 & 149 & 89 & 238 \\
\hline T4: Sugargraze (seed rate $9.5 \mathrm{~kg} / \mathrm{ha}$ ) & 564 & 334 & 898 & 151 & 90 & 241 \\
\hline $\begin{array}{l}\text { T5: Sugargraze (seed rate } 11.5 \\
\mathrm{~kg} / \mathrm{ha} \text { ) }\end{array}$ & 514 & 262 & 776 & 134 & 66 & 200 \\
\hline $\begin{array}{l}\text { T6: Local chari (seed rate } 10.0 \\
\text { kg/ha) }\end{array}$ & 409 & 250 & 659 & 109 & 57 & 166 \\
\hline SEm \pm & 3.58 & 2.68 & - & 1.00 & 0.59 & - \\
\hline CD at $5 \%$ & 10.41 & 7.77 & - & 2.90 & 1.69 & - \\
\hline
\end{tabular}


Sowing of sugargraze by $9.5 \mathrm{~kg}$ seed/ha gave higher fodder yield over local chari sowing by $10.0 \mathrm{~kg} \mathrm{seed} / \mathrm{ha}$. Sugargraze also recorded better quality in term of cruid protein, cruid fibre and ash and it may be suitable for green fodder purpose.

\section{References}

Dehinwal, A. K., S. K. Pahuja and M. Shafiqurrahaman, 2016. Environmental effect on sorghum fodder yield and its related traits. Forage Res.42: pp.189-194.

Jan, A., Kaleem, S.A., Taj, F.H. and Khan, H. 2000. Response of moongbean cultivars to different seeding densities at dry land conditions. Pakistan J. Biol. Sci., 3: 2030-32.

Kumar, D. and P. C. Chaplot. 2015.
Performance of multicut forage sorghum genotypes to fertility levels. Forage Res.41: 199-201.

Robert, W. and Singh, K. 1981. Food Grain, A Text Book of Punjab Agriculture, Civil and Ministry Gazette, Lahore. 287.

Smith, H.J., B.M. Tast, H.Z. Taweet, S. Tammingat and A. Elgersma, 2005. Effect of perennial ryegrass (Lolium perenne L.) cultivars on herbage production, nutritional quality and herbage intake of grazing dairy cows. Grass and Forage Science60: 297- 309.

Satpal, Dhun, B. S., Arya, S., PummyKumari and Devi, S. 2016. Performance of single cut forage sorghum genotypes to different fertility levels. Forage Res., 42:184-188.

\section{How to cite this article:}

Harphool Meena, Pratap Singh, S. N. Meena, D. L. Yadav and Meena. N. L. 2020. Performance of Hybrid Fodder Sorghum (Sugargraze). Int.J.Curr.Microbiol.App.Sci. 9(05): 1601-1606. doi: https://doi.org/10.20546/ijcmas.2020.905.181 